Provided for non-commercial research and education use. Not for reproduction, distribution or commercial use.

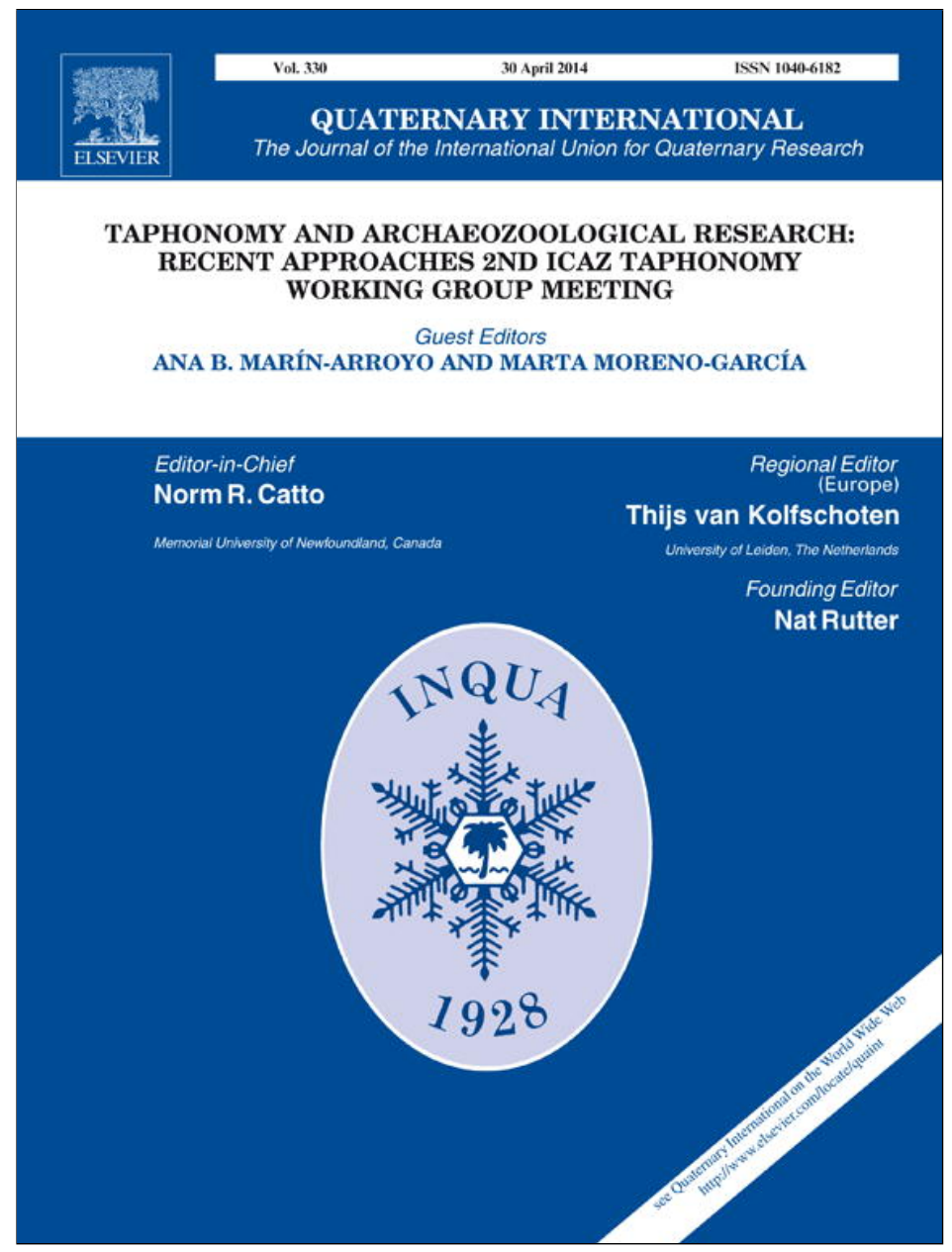

This article appeared in a journal published by Elsevier. The attached copy is furnished to the author for internal non-commercial research and education use, including for instruction at the authors institution and sharing with colleagues.

Other uses, including reproduction and distribution, or selling or licensing copies, or posting to personal, institutional or third party websites are prohibited.

In most cases authors are permitted to post their version of the article (e.g. in Word or Tex form) to their personal website or institutional repository. Authors requiring further information regarding Elsevier's archiving and manuscript policies are encouraged to visit:

http://www.elsevier.com/authorsrights 


\title{
Towards the identification of a new taphonomic agent: An analysis of bone accumulations obtained from modern Egyptian vulture (Neophron percnopterus) nests
}

\author{
Alfred Sanchis Serra ${ }^{a, *}$, Cristina Real Margalef ${ }^{b}$, Juan V. Morales Pérez ${ }^{b}$, \\ Manuel Pérez Ripoll ${ }^{b}$, Carmen Tormo Cuñat ${ }^{a}$, Yolanda Carrión Marco ${ }^{c}$, \\ Guillem Pérez Jordá d , Agustí Ribera Gómez ${ }^{e}$, Joaquim Bolufer Marqués ${ }^{\mathrm{f}}$, \\ Valentín Villaverde Bonilla ${ }^{\mathrm{b}}$ \\ ${ }^{a}$ Museu de Prehistòria de València, Servei d'Investigació Prehistòrica, Diputació de València, Corona 36, 46003 València, Spain \\ ${ }^{\mathrm{b}}$ Departament de Prehistòria i Arqueologia, Universitat de València, Blasco Ibáñez 28, 46010 València, Spain \\ ${ }^{c}$ Universidad Nacional de Educación a Distancia (UNED), Casa de la Misericordia 34, 46014 València, Spain \\ d GI Bioarqueología, IH, CCHS, CSIC, Madrid, Spain \\ e Museu Arqueològic d'Ontinyent i la Vall d'Albaida (MAOVA), Spain \\ ${ }^{\mathrm{f}}$ Museu Arqueològic i Etnogràfic Municipal, Xàbia, Spain
}

\section{A R T I C L E I N F O}

\section{Article history:}

Available online 7 November 2013

\begin{abstract}
A B S T R A C T
This paper presents the results of a study of bones recovered in various current Egyptian vulture (Neophron percnopterus) nests in a Mediterranean region of the Iberian Peninsula. The Egyptian vulture, a diurnal, scavenging, rupicolous bird of prey, is one of four vulture species that currently inhabit the Iberian Peninsula. An analysis of the remains found in the nests confirms that it has a heterogeneous diet that includes remains from human activities (butchery and food production) and the carcasses of dead animals, although it is possible that they also prey on small-sized taxa. The taphonomic study determines these birds' capability of transporting, accumulating and altering bone remains. Some of the elements show marks caused by beak and/or claw impacts brought about primarily during feeding, which have characteristic typologies. Despite the fact that this is not a bone-eating vulture, it can also be seen that some bones are swallowed. The characteristics of the bone set studied here are important for establishing the origin of bone accumulations on archaeological sites.
\end{abstract}

(c) 2013 Elsevier Ltd and INQUA. All rights reserved.

\section{Introduction}

Various studies have been carried out in Europe in recent years to characterise the bone accumulating and altering habits of birds of prey and their archaeological implications (e.g. Andrews, 1990; Guillem and Martínez Valle, 1991; Sanchis, 2000; Robert and Vigne, 2002a, b; Bochenski and Tornberg, 2003; Cochard, 2004; Laroulandie, 2005; Bochenski, 2005; Lloveras et al., 2008, 2009; Bochenski et al., 2009). In this regard, it has been shown at various archaeological sites that these birds play an active role in the formation of bone sets (Robert and Vigne, 2002a, b; Davis et al., 2007; Costamagno et al., 2008; Marín-Arroyo et al., 2009; Sanchis, 2012), indicating that there are processes of interaction with the

\footnotetext{
* Corresponding author.

E-mail address: alfred.sanchis@dival.es (A. Sanchis Serra).
}

humans who inhabit the same places. In general, more attention has been paid to birds that prey on other animals, but the role played in these situations by scavenging birds, especially vultures, is less well known (Robert and Vigne, 2002a, b; Marín-Arroyo et al., 2009; Marín-Arroyo and Margalida, 2012).

Nowadays, four species of vultures breed in the Iberian Peninsula: the Eurasian griffon vulture (Gyps fulvus Hablizl 1783), the Eurasian black vulture (Aegypius monachus Linnaeus 1766), the bearded vulture (Gypaetus barbatus Linnaeus 1758) and the Egyptian vulture (Neophron percnopterus Linnaeus 1758). However, the only neotaphonomic studies that have been carried out are about the bone-eating species, the bearded vulture (Marín-Arroyo et al., 2009; Marín-Arroyo and Margalida, 2012). Our study is justified on the basis that nothing is known about the bone accumulating and modifying habits of other non-bone-eating species, primarily birds that peck at soft tissue. 
The Egyptian vulture is a medium-sized diurnal raptor whose behaviour could be described as scavenging, opportunistic and coprophagous (Donázar, 1993). But although it is essentially a carrion-eating bird, it can also catch live prey and even feed on organic waste. Its feeding habits depend to a large extent on human activities (Gallardo and Penteriani, 2002-2007). It is a seasonal inhabitant of the Iberian Peninsula (spring and summer), where it reproduces and roosts on cliffs and rocks (e.g. Ceballos and Donázar, 1988; Donázar and Ceballos, 1988; Donázar, 1993, 2004; Dies, 2004; Hidalgo et al., 2005; López and García-Ripollés, 2007; Margalida et al., 2012a). The Egyptian vulture has been defined by Kruuk (1967) and by König (1983) as a pecking carrion bird that prefers soft tissue. It is the smallest of the Iberian vultures and its beak is short and thin compared with that of other vultures. It uses its beak to rip off pieces of flesh and fat, reaching every part of bones, which it keeps under its claws while feeding (Gallardo and Penteriani, 2002-2007).

The fossil record shows a few references for this vulture in the Iberian Peninsula during the late Pleistocene, including Boquete de Zafarraya in Andalusia (Hernández Carrasquilla, 1994) and Urtiaga in the Basque Country (Elorza, 1990), although it occasionally appears in Holocene archaeological contexts as well (Lauk, 1976; Boessneck and von den Driesch, 1980).

This paper presents the results of a taphonomic study of a modern bone set from several Egyptian vulture nests located in the Benaxuai caves at $420 \mathrm{~m}$ above sea level in an inland area of Valencia in the Mediterranean region of the Iberian Peninsula. Preliminary studies of the superficial bones recovered in caves C2 and C12-13 (Sanchis et al., 2010, 2011a) showed a heterogeneous assemblage characterised by: 1) a wide range of prey; 2) mostly pitted and punctured bones; 3 ) low quantities of ingested remains based on the lack of pellets. Both the features of the assemblage and the information supplied suggest that the presence of these bones in the caves is related to the activities of this vulture. Given the importance of having a referent for this species, it was necessary to carry out a systematic excavation of $\mathrm{C} 2$ in order to confirm or obtain new data about the behaviour of this taphonomic agent. The excavation of $\mathrm{C} 2$ has yielded a very extensive sample that has shed light on the model of accumulation and alteration of the bone remains found in Egyptian vulture nests. While in previous studies the data were very general and came from a limited set, this study has provided some very detailed information about the species that make up the diet of theses vultures, anatomical representation and age on death of their prey, as well as the state of conservation, description and quantification of alterations to the remains.

\section{Materials and methods}

\subsection{Study area}

The habitat is that of a Mediterranean riverside scrubland biotope near the town of Chelva (eastern Spain), an area that is dominated by farmland. The assemblages were recovered in a window cave ( $\mathrm{C} 2$ ). These structures are artificial caves, formed by one or more chambers excavated in cliff walls, which were used as storage chambers during the Middle Ages. The Benaxuai caves are situated in the middle of a large, shady, north-facing rock face that is $50 \mathrm{~m}$ long and $30 \mathrm{~m}$ high (Ribera and Bolufer, 2008; Ribera, 2010). Once the humans left the cavities, they were occupied by these vultures. The location of these structures, at a height of between 10 and $20 \mathrm{~m}$ above the current riverbed, makes it very difficult to access them without using ropes, ladders or climbing gear, which rules out the possibility of intrusion by terrestrial predators (Fig. 1).

\subsection{Systematic excavation of $\mathrm{C} 2$}

This cave is an area of $8 \mathrm{~m}^{2}$ that was chosen because it is the only cave with an intact structure that still possesses a major sedimentary package $(20-45 \mathrm{~cm})$. Before excavation, the accumulation of branches, wool and bones could be seen on the floor of the cave, forming various nests that had remained intact until our intervention (Fig. 2a, c). The material linked to these structures was distributed throughout much of the site, but was concentrated to some extent at the back of the main chamber (Fig. 2a).

The sediment obtained during the excavation process was sieved through a $1-\mathrm{mm}$ mesh, making it possible to recover the remains of small animal and plant species.

Two main levels were identified inside the cave (Fig. 2b):

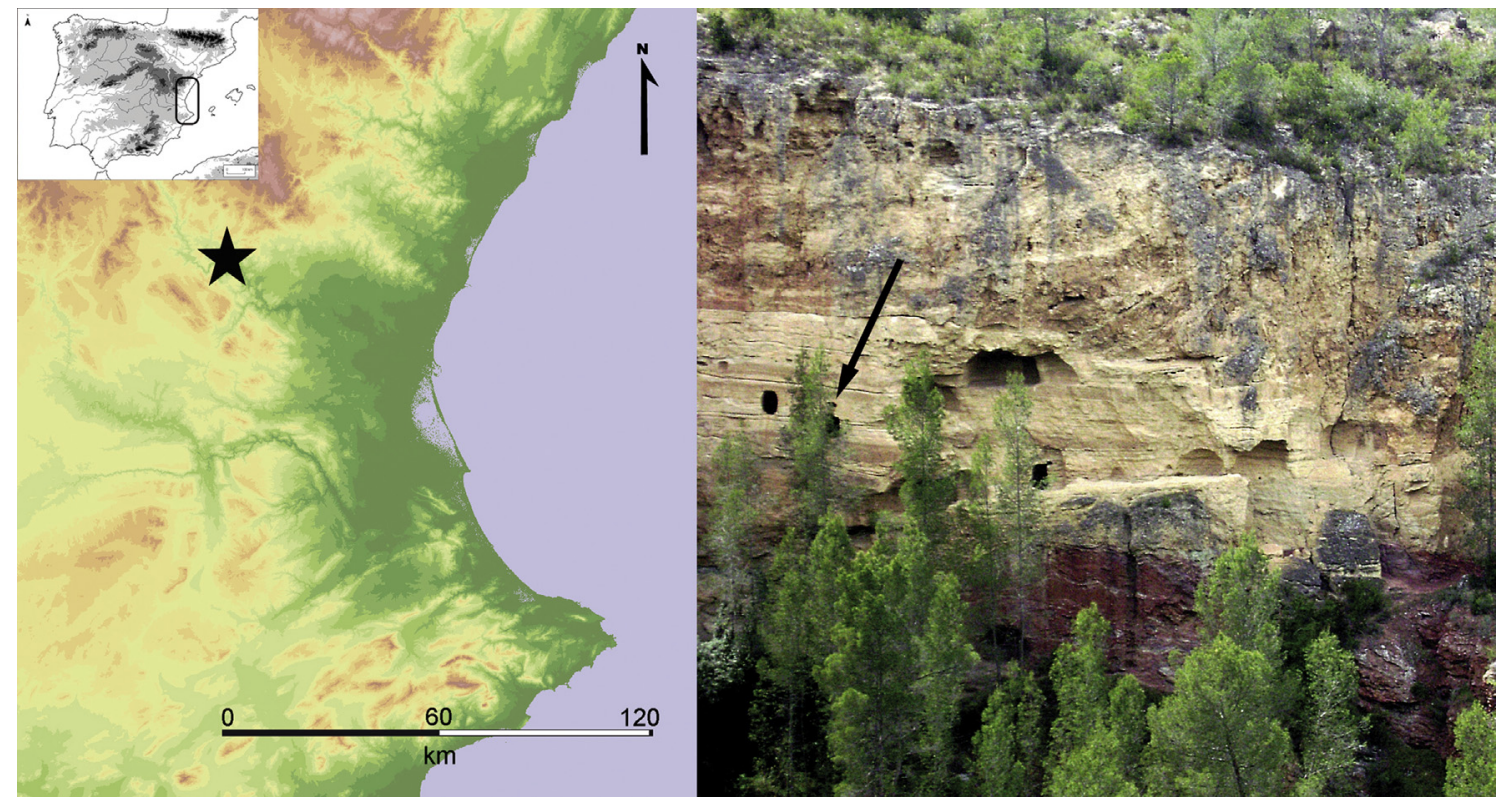

Fig. 1. Location of Benaxuai caves (left). View of the Benaxuai caves. The arrow indicates the C2 structure (right). 

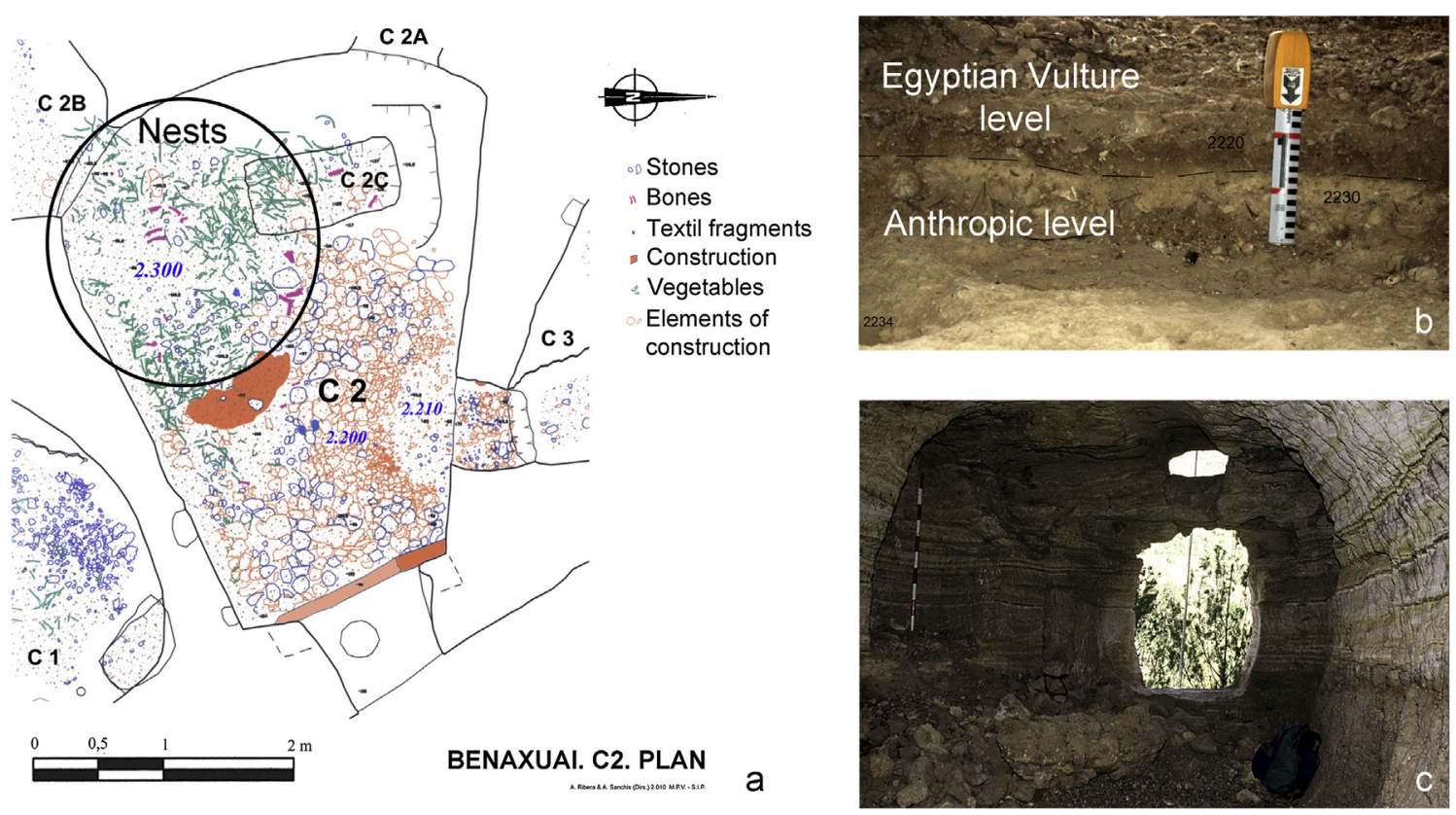

Fig. 2. a) Planimetry of the $\mathrm{C} 2$ structure with the situation of the Egyptian vulture nests. b) Stratigraphic section with the main occupation levels. c) Interior view of $\mathrm{C} 2$ before the systematic excavation in 2010.

a) Lower level. This yielded archaeological artefacts such as pottery, paper, rope, wood and building materials and cloth resulting from the use of this structure as a grain store during the Middle Ages.

b) Upper level. This was characterised by the presence of bones and other organic matter (branches, seeds, fruits, fleece, fragments of excrement and pellets) from the vulture nests, which had also led to bioturbation on the lower level. It is not known exactly how many nests there are, although based on the level and amount of material recovered, there seem to have been several occupations.

\subsection{Materials of animal origin}

The faunal sample recovered in C2 was comprised of elements from various species of vertebrates. Soft tissue (skin and tendons) was still attached to some of these remains due to the almost complete lack of humidity in the cave. In this case, it was necessary to boil the remains in water for $2 \mathrm{~h}$ in order to separate the soft tissue so that they could be studied and preserved. The materials were then submerged in acetone for a further $2 \mathrm{~h}$, making it possible to remove their fat content. This treatment proved to be sufficient to reveal the bone surfaces and describe any marks on them.

The taxonomic identification of faunal remains was carried out using collections from the Gabinet de Fauna Quaternària del Museu de Prehistòria de València (Prehistory Museum of Valencia's Department of Quaternary Fauna).

The number of identified specimens (NISP) of each taxon was established as the primary unit of quantification. The minimum number of skeletal elements (MNE) for each bone and minimum number of individuals (MNI) for each taxon were also calculated (Reitz and Wing, 1999; Lyman, 2008), as well as the percentage of representation (\%R) proposed by Dodson and Wexlar (1979). For a detailed description of how these calculations have been made, see Sanchis (2012: 73-75).

To establish the age at death we analysed tooth eruption sequences and the extent of tooth wear, as well as studying the degree of joint fusion (Silver, 1969; Bull and Payne, 1982; Payne, 1982;
Hillson, 1986; Horard-Herbin, 2000; Sanchis, 2012). These criteria were used to define three cohorts: juvenile (with deciduous dentition and non-fused elements that had not yet reached adult size), subadult (permanent dentition with little or no wear, partial joint fusion and adult size) and adult (permanent dentition with wear and complete joint fusion). For birds, joint fusion and the size of the remains have been taken into consideration: adults with complete fusion; subadults with partial fusion and adult size; juveniles with non-fused elements and smaller size.

The nature of bone breakage (fresh or dry) was defined according to the work of Villa and Mahieu (1991). The length of all the remains was measured (in $\mathrm{mm}$ ), except for those with recent fractures, to ascertain the level of fragmentation. Five categories were created: $<25 \mathrm{~mm}, 25-50 \mathrm{~mm}, 51-75 \mathrm{~mm}, 76-100 \mathrm{~mm}$ and $>100 \mathrm{~mm}$. The morphotypes observed are described for each anatomical element in the main species.

Apart from the generic beak impact marks -defined as punctures- mentioned in various studies (Laroulandie, 2005; Lloveras et al., 2008, 2009; Bochenski et al., 2009), we believe it is important to add some further morphotypes in view of the variety of alterations we observed in the sample studied. These modifications have been classified as (Binford, 1981: 44; Laroulandie, 2005; Sanchis et al., 2011b):

- Notch: bone loss on the edge of the fracture that can result in an oblique, concave indentation on the inner wall.

- Puncture: complete perforation of the bone.

- Crushing: inward perforation of the bone wall into the cortical bone, which normally occurs in areas of low-density or spongy bone.

- Pit: superficial modification of the bone wall with a subcircular morphology.

- Crenulated edges: the edge of the fracture has a series of indentations.

In addition to these alterations, they have been classified by morphology (oval, circular, triangular, etc.), distribution (unilateral or bilateral) and number (isolated or multiple). These alterations have been described for the main taxa and counted by anatomical 
elements and groups. The dimensions of beak impact marks (length and width in $\mathrm{mm}$ ) have also been given.

As regards digested remains, the number of alterations was counted in terms of anatomical elements and groups. We took into account whether they were complete bones or fragments and whether they had been fully or partially digested. Different categories of alteration were also recorded: porosity, polish, bone loss or deformation and whether they were associated with mechanical alterations. The length of digested remains was recorded (in $\mathrm{mm}$ ). We took into account a range of methodologies when defining these alterations (Andrews, 1990; Lloveras et al., 2008, 2009; Marín-Arroyo et al., 2009).

Given that the Egyptian vulture is a scavenging bird, one of the possibilities that should be taken into account with regard to the bone set in question is that some of the remains brought to the nests by these vultures may have been manipulated and altered previously by other birds or terrestrial carnivores, as has been observed in bearded vulture ossuaries (Robert and Vigne, 2002b). We have no proof of this, or indeed that $\mathrm{C} 2$ was occupied subsequently by other birds. It is not feasible that a carnivore such as the beech marten (Martes foina) or fox (Vulpes vulpes) could have entered the cave, as it is situated on a vertical wall rising more than $10 \mathrm{~m}$ from the ground, as described above.

\subsection{Materials of plant origin}

Branches from the levels accumulated by the vultures had been preserved as fresh wood thanks to favourable environmental conditions in the cavities, although xylophagous microorganisms were often present, and wood decay often made it difficult or even impossible to analyse some branches. Xylem fragments were the most common remains, although other vegetative organs such as seeds, fruits or leaves have been more sporadically documented.

\subsubsection{Wood}

Both macro- and microscopic observation were used to study pieces of wood. Microscopic analysis was used to determine the botanical identity of the wood. For this task, the anatomical patterns of each wood were observed in all three sections -cross, tangential and radial- under a Nikon Optiphot-100 dark/bright field incident light microscope with 50-500× magnifications and they were compared with specialised plant anatomy atlases (Greguss, 1955, 1959; Schweingruber, 1990) and the reference collection of modern Mediterranean charred woods from the laboratory of the Departament de Prehistòria i Arqueologia de la Universitat de València (University of Valencia's Department of Prehistory and Archaeology).

Thanks to the fact that the bark had been preserved on many branches, we were able to estimate the season when they were cut. This information was obtained by observing the characteristics of the last annual growth ring in relation to the bark. The presence of latewood in the last annual ring indicates that the branch was cut during the least favourable season for plant growth, which is after the summer. When earlywood has started to form, this indicates that it was cut in spring. This could indicate that the input of branches, and thus the presence of the vultures in the cavity, is seasonal. But it should be mentioned that Egyptian vultures could also have collected branches that had already been cut from the ground in order to build their nests. In any case, certain types of cut seem to suggest that they may sometimes have been cut expressly by these vultures.

Photography and detailed observation was carried out using a Hitachi S-4100 Field Emission Scanning Electron Microscope and EMIP 3.0 (Electron Microscope Image Processing) software at the
Universitat de València's Experimental Research Support Service (SCSIE).

Macro-analysis included measuring the diameter of the branches and other wood anatomy features, observed under low magnification through a binocular lens $(20-50 \times)$. The morphology of the ends of the branches was observed in order to assess whether the vultures cut them directly from the living plant or whether the cut resulted from secondary fractures, in which case the vultures would have used pieces that had already been cut, possibly from the archaeological levels.

\subsubsection{Seeds and fruits}

The taxonomic identification was carried out using morphological criteria, examining the morphological and biometric characteristics of each taxon. They were examined under a stereoscopic microscope and compared against various identification atlases (Zohary and Hopf, 1993; Cappers et al., 2006) and the reference collection. The materials were not charred, which made them easier to identify, as they had undergone less alteration and this allowed us to assess aspects such as their consumption or the possibility that some of them might have been digested.

\section{Results}

\subsection{Analysis of a modern bone assemblage}

\subsubsection{Quantification, taxonomy and mortality profiles}

The set of bone remains recovered is large enough (2456 elements) and is formed by both isolated (1713) and anatomical connection elements (ACE) (743). Of the bones, 1825 (76\%) were identified taxonomically and anatomically (NISP), corresponding to 124 individuals. The sample is characterised by its taxonomical heterogeneity (Fig. 3). The largest group in terms of NISP and MNI consists of medium-sized domestic ungulates, predominantly sheep and goat (27.9\% of NISP). The second group comprises both domestic (cat and dog with $9.6 \%$ and $8.3 \%$, respectively) and wild (especially fox and badger with $3.2 \%$ and $1.1 \%$, respectively) carnivores. Another important group is formed by both genera of leporid (rabbit and hare with 14.7\%). As regards birds (9.3\%), chicken (4\%) and immature Egyptian vulture $(0.8 \%)$ bones were found. We also found remains of small mammals (3.6\%), amphibians (especially toad with $0.7 \%$ ), reptiles (mainly ladder snake and ocellated lizard with $9.4 \%$ and $5 \%$, respectively), fish $(0.3 \%)$, gastropods $(0.2 \%)$ and insects $(0.2 \%)$. The remains of eggshells were identified, the colouring and external morphology of which appear to coincide with Egyptian vulture eggs. Remains of mammalian excrement were also found in the sample.

As regards the mortality profiles (Fig. 4), in domestic ungulates (sheep and goat) there is a predominance (\%MNI) of juveniles (29.4\%) and especially subadults (64.7\%). On the other hand, both domestic and wild carnivores and leporids show the opposite behaviour, with more deaths among adults (natural deaths and/or predation). Adults represent $41.7 \%$ in leporids, $50 \%$ in dogs and foxes and $69.2 \%$ in cats. For chickens, there was a predominance of adult individuals (71.4\%), with few subadults and no juveniles.

\subsubsection{Anatomical representation}

In relation to the presence of anatomical elements (\%R), taking into account the MNE and their theoretical frequency, there are differences according to taxa (Fig. 5).

In sheep and goats there were high percentages for scapula (67.6\%), pelvis (52.9\%) and maxilla (44.1\%), followed by humerus (32.3\%) and femur (32.3\%), with a lower representation for radius/ ulna (13.2\%), mandible (26.5\%) and fore (21.7\%) and hind (28.7\%) vertebrae, and very few for carpus (1\%), tarsus (12.3\%), metapodial 


\begin{tabular}{|c|c|c|c|}
\hline TAXA & NISP & \%NISP & $\overline{\mathrm{MNI}}$ \\
\hline Domestic ungulates & 577 & 31.62 & 25 \\
\hline Bos taurus & 5 & 0.27 & 1 \\
\hline Equus sp. & 35 & 1.92 & 4 \\
\hline Equus cf. asinus & 1 & 0.05 & 1 \\
\hline Capra hircus & 62 & 3.40 & 4 \\
\hline Ovis aries & 28 & 1.53 & 2 \\
\hline Ovis/Capra ind. & 420 & 23.01 & 11 \\
\hline Sus sp. & 26 & 1.42 & 2 \\
\hline Domestic carnivores & 327 & 17.92 & 21 \\
\hline Canis familiaris & 152 & 8.33 & 8 \\
\hline Felis sp. & 175 & 9.59 & 13 \\
\hline Wild carnivores & 83 & 4.55 & 8 \\
\hline Vulpes vulpes & 59 & 3.23 & 4 \\
\hline Martes foina & 4 & 0.22 & 1 \\
\hline Meles meles & 20 & 1.10 & 3 \\
\hline Carnivores & 11 & 0.60 & \\
\hline Canidae & 10 & 0.55 & \\
\hline Indeterminate carnivore & 1 & 0.05 & \\
\hline Leporids & 269 & 14.74 & 11 \\
\hline Oryctolagus cuniculus & 89 & 4.88 & 5 \\
\hline Lepus sp. & 69 & 3.78 & 3 \\
\hline Leporidae & 111 & 6.08 & 3 \\
\hline Micromammals & 66 & 3.62 & 6 \\
\hline Arvicola terrestris & 1 & 0.05 & 1 \\
\hline Eliomys quercinus & 19 & 1.04 & 1 \\
\hline Mus musculus & 2 & 0.11 & 1 \\
\hline Rattus rattus & 43 & 2.36 & 2 \\
\hline Muridae & 1 & 0.05 & 1 \\
\hline Birds & 169 & 9.26 & 14 \\
\hline Gallus gallus & 74 & 4.05 & 9 \\
\hline Neophron percnopterus & 15 & 0.82 & 2 \\
\hline Indeterminate birds & 80 & 4.38 & 3 \\
\hline Amphibians & 17 & 0.93 & 7 \\
\hline Bufo sp. & 13 & 0.71 & 5 \\
\hline Rana sp. & 2 & 0.11 & 1 \\
\hline Anura & 2 & 0.11 & 1 \\
\hline Reptiles & 293 & 16.05 & 26 \\
\hline Lacerta lepida & 91 & 4.99 & 15 \\
\hline Mauremys leprosa & 5 & 0.27 & 1 \\
\hline Rhinechis scalaris & 171 & 9.37 & 7 \\
\hline Culebridae & 20 & 1.10 & 1 \\
\hline Ophidia & 4 & 0.22 & 1 \\
\hline Sauria & 2 & 0.11 & 1 \\
\hline Fish & 6 & 0.33 & 1 \\
\hline Gadus morhua & 1 & 0.05 & 1 \\
\hline Indeterminate fish & 5 & 0.27 & \\
\hline Gastropods & 4 & 0.22 & 4 \\
\hline Helicidae & 2 & 0.11 & 2 \\
\hline Otala punctata & 1 & 0.05 & 1 \\
\hline Rumina decollata & 1 & 0.05 & 1 \\
\hline Insects & 3 & 0.16 & 1 \\
\hline Coleoptera & 3 & 0.16 & 1 \\
\hline TOTAL & 1825 & & 124 \\
\hline
\end{tabular}

Fig. 3. Faunal species identified in C2 (NISP, \%NISP and MNI).

bones (2.9\%/5.9\%), phalanges (2\%) and ribs (9.6\%). There were few remains of species of large ungulates, which included elements of equine posterior limbs.

As regards dogs, the bones are predominantly the scapula and the radius/ulna (62.5\%), followed by the pelvis (43.7\%), mandible (37.5\%) and humerus (37.5\%); the representation percentages are

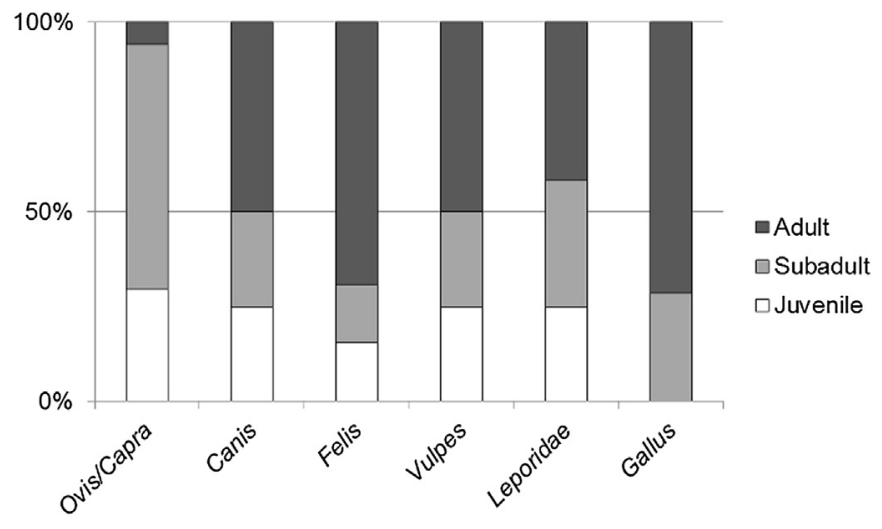

Fig. 4. Mortality profiles of main faunal species (\%MNI). very low for the tibia/fibula (15.6\%), carpus (7.1\%), metacarpus (6.2\%), phalanges (4.6\%), fore (10.5\%) and hind (1.6\%) vertebrae and ribs (5.7\%). The most represented cat and fox bone is the mandible (80.8\% and $75 \%$, respectively), although there are also important percentages for the femur ( $42.3 \%$ and $25 \%$ ), pelvis (34.6\% in cats, but $50 \%$ in foxes), scapula (34.6\% and $62.5 \%$ ) and radius/ulna (30.8\% in cats), and lower percentages for the maxilla (26.9\% and $37.5 \%)$, fore (16.2\% and $13.2 \%$ ) and hind $(20.1 \%$ in cats, but $53.1 \%$ in foxes) vertebrae, tibia/fibula ( $21.1 \%$ and $12.5 \%)$, carpus $(0 \%)$, ribs $(0.3 \%$ in cats) and humerus (5.8\% in cats, but $25 \%$ in foxes).

The most common bones for leporids are the femur (45.4\%), pelvis (36.4\%) and radius/ulna (31.8\%), followed by the metatarsus (25\%), humerus (22.7\%), carpus (19.5\%) and hind vertebrae (18.2\%); there are fewer examples for the mandible (4.5\%), phalanges (11.7\%), metacarpus (11.8\%), scapula (13.6\%), tarsus (14.9\%) and tibia/fibula (15.9\%) and very few for the sesamoids (5.4\%), fore vertebrae $(2.9 \%)$ and maxilla (4.5\%).

The most numerous bones from chickens are the sternum (100\%), followed by the tarsometatarsus (66.7\%), femur (50\%), pelvis (27.8\%) and radius/ulna (16.7\%), with very few examples for the carpometacarpus (11.1\%), vertebrae (11.1\%) and phalanges (4.6\%).

A chi-square analysis has confirmed that the differences among the distribution of bones sorted by anatomical groups (cranial, fore limbs, axial, hind limbs and autopodium - see Fig. 5) are statistically significant every pair of taxa $(d f=4 ; P<0.05)$, except for two cases. The differences are no significant between Vulpes and Felis $\left(\chi^{2}=0.79 ; d f=3 ; P=0.522\right)$ and Ovis/Capra and Vulpes $\left(\chi^{2}=6.12\right.$; $d f=4 ; P=0.191)$. However the fact that the NISP of Vulpes is the most reduced must be taken into account in these two cases. We found a total of 165 groups of ACE, particularly from sheep/goats and cats (mainly vertebrae), leporids and dogs (mainly limbs).

\subsubsection{Fragmentation}

Just over half of the sample is fragmented (54.9\%), corresponding primarily to isolated elements (88.6\%) and to a lesser extent ACE (11.4\%). However, of the non-fragmented elements, ACE account for $79.4 \%$, while isolated elements only represent $30.2 \%$. The largest group of fragments is those measuring $<50 \mathrm{~mm}$ (Fig. 6): $<25 \mathrm{~mm}$ (35.9\%), 25-50 mm (30.2\%), 51-75 mm (15.2\%), 76-100 mm (9.9\%), $>100 \mathrm{~mm}(8.7 \%)$, with an average length of $46.6 \mathrm{~mm}$. As regards taxonomic groups, two sets can be distinguished: on the one hand, sheep and goats show more fragmentary remains ( $80 \%$ fragmented remains), which is logical considering that these remains come from human rubbish dumps, and on the other hand, leporids and carnivores show more complete elements, with between 20 and $25 \%$ representing fragmented remains, respectively (predation and/ or natural deaths). The differences between these two groups in terms of complete and fragmented bones are statistically significant $\left(\chi^{2}=404.31 ; d f=1 ; P=0.001\right)$.

\subsubsection{Main fracture morphotypes by element}

- Mandible. We see complete mandibles of domestic carnivores that are missing part of the ramus and which show notches (Fig. 7a). These are related to the removal of the masseter muscle and disarticulation from the cranium.

- Long bones. The most interesting feature is the lack of diaphyseal cylinders or longitudinal fragments of this type of bone. The ungulate remains include many epiphyses with bone loss and bones with complete epiphyses joined to various sizes of diaphysis fragments (normally $<50 \%$ of the length), with few elements showing complete loss of the articular bone. Among the leporids, there are fragments showing complete epiphyses 


\begin{tabular}{|c|c|c|c|c|c|c|c|c|c|c|c|c|}
\hline & \multicolumn{2}{|c|}{ Ovis/Capra } & \multicolumn{2}{|c|}{ Canis } & \multicolumn{2}{|c|}{ Felis } & \multicolumn{2}{|c|}{ Vulpes } & \multicolumn{2}{|c|}{ Leporidae } & \multicolumn{2}{|c|}{ Gallus } \\
\hline & MNE & $\% R$ & MNE & $\% R$ & MNE & $\% R$ & MNE & $\% R$ & MNE & $\% R$ & MNE & $\% R$ \\
\hline Cranial & 24 & & 10 & & 28 & & 9 & & 4 & & 0 & \\
\hline Mandible & 9 & 26.47 & 6 & 37.50 & 21 & 80.77 & 6 & 75.00 & 3 & 13.64 & & \\
\hline Maxilla & 15 & 44.12 & 4 & 25.00 & 7 & 26.92 & 3 & 37.50 & 1 & 4.55 & & \\
\hline Fore limbs & 46 & & 49 & & 20 & & 11 & & 65 & & 8 & \\
\hline Scapula & 23 & 67.65 & 10 & 62.50 & 9 & 34.62 & 5 & 62.50 & 3 & 13.64 & & \\
\hline Humerus & 11 & 32.35 & 6 & 37.50 & 3 & 5.77 & 2 & 25.00 & 5 & 22.73 & & \\
\hline Radius/Ulna & 9 & 13.24 & 20 & 62.50 & 8 & 30.77 & & & 14 & 31.82 & 6 & 16.67 \\
\hline Carpal & 2 & 0.98 & 8 & 7.14 & & & & & 30 & 19.48 & ? & 1111 \\
\hline Axial & 148 & & 28 & & 75 & & 27 & & 22 & & 10 & \\
\hline Ribs & 39 & 9.56 & 11 & 5.73 & 1 & 0.32 & & & & & & \\
\hline Sternum & & & & & & & & & & & 9 & 100.00 \\
\hline Fore vertebrae & 70 & 21.67 & 16 & 10.53 & 40 & 16.19 & 10 & 13.16 & 6 & 2.87 & & \\
\hline Hind vertebrae & 39 & 28.68 & 1 & 1.56 & 34 & 20.12 & 17 & 53.15 & 16 & 18.18 & 1 & 11.11 \\
\hline Hind limbs & 59 & & 26 & & 32 & & 8 & & 70 & & 26 & \\
\hline Pelvis & 18 & 52.94 & 7 & 43.75 & 9 & 34.62 & 4 & 50.00 & 8 & 36.36 & 5 & 27.78 \\
\hline Femur & 11 & 32.35 & 3 & 18.75 & 11 & 42.31 & 2 & 25.00 & 10 & 45.45 & 9 & 50.00 \\
\hline Tibia/Fibula & 7 & 10.29 & 5 & 15.63 & 11 & 21.15 & 2 & 12.50 & 7 & 15.91 & & \\
\hline Metatarsal & 2 & 5.88 & 7 & 10.94 & & & & & 22 & 25.00 & 12 & 66.67 \\
\hline Autopodium & 9 & & 19 & & 0 & & 0 & & 86 & & 15 & \\
\hline Sesamoid & 1 & 0.25 & & & & & & & 19 & 5.40 & & \\
\hline Phalanges & 8 & 1.96 & 19 & 4.57 & & & & & 67 & 11.71 & 15 & 4.63 \\
\hline & 286 & & 132 & & 155 & & 55 & & 247 & & 59 & \\
\hline
\end{tabular}

Fig. 5. Anatomical representation of main faunal species (MNE and \%R).

joined to diaphyses that have retained between 50 and $75 \%$ of their length (Fig. 7c). The long bones of chickens that were found are epiphyses broken in half or long bones with diaphyses measuring between 25 and $50 \%$ of their length.

- Scapula. Almost complete elements are predominant in all taxa, conserving $>50 \%$ of their length (they are only missing certain small fragments). These are associated with beak impacts relating to the consumption of soft parts (Fig. 7c). Fragments of the body of the bone without articular ends have also been documented for ungulates.

- Pelvis. A single morphotype has been documented for domestic carnivores, which is the almost complete pelvis missing part of the ilium, which is associated with beak impacts related to access to soft parts. Ungulates and chickens show almost complete fragments with loss of a proximal or distal fragment related to beak impacts and cut marks (human butchery process); the second most important morphotype of ungulate pelvis is ilium fragments. For leporids we found almost complete pelvis with loss of a distal fragment (Fig. 7a).

- Ribs. Most of the rib remains are from medium-sized animals and have fresh fracture morphotypes: complete bodies, elements with the anterior half conserved, which are associated with crenulated edges and cut marks (human butchery process).

\subsubsection{Mechanical alterations: beak and/or claw impacts}

Of the total remains, 26.7\% (655) show alterations caused by beak/claw impacts. A further $9.6 \%$ of the remains show cut marks, mainly on domestic ungulate bones and other remains from butchery and human consumption (Fig. 7f). Bearing in mind the number of remains with non-human alterations, which are related mainly to the action of the Egyptian vultures, these modifications include notches (7.2\%), pits (5.6\%), punctures (2.2\%) and crenulated edges (5.3\%), although bone loss (3.2\%), crushes (1.5\%), and scrapes (0.8\%) were also identified (Fig. $7 \mathrm{a}-\mathrm{e}$ ).

The main morphologies of notches (Fig. 7a) are semicircular (47.6\%), triangular (38.2\%) and rectangular (8.3\%). Notches largely have an isolated (75.6\%) and unilateral (92\%) distribution. They are most common in the cranium and axial skeleton (Fig. 8). As regards pits (Fig. 7b), most of the alterations are oval (57.5\%), circular (16.7\%) or triangular (12\%) with a unilateral distribution (92\%) and either isolated $(50 \%)$ or multiple (50\%). They are predominantly found in bones of the anterior and posterior limbs (Fig. 8). Overlapping pits caused by repeated beak action are frequently seen (Fig. 7b). Thirdly, there are punctures (Fig. 7c), which mostly have an oval (59\%) and circular (23\%) shape, with a unilateral (94\%) and isolated (78\%) distribution. They are less frequent than the other types of alteration and their distribution is more or less similar for all bones, although they are often present in the scapula (Fig. 8). A more precise description of the distribution of the different alterations caused by beak or claw impacts in the different areas or anatomical elements is given below:

- Cranium. Notches in the remains of domestic carnivores are chiefly found in the posterior section, whereas in leporids, ungulates and wild carnivores they are distributed across medial and posterior areas (Fig. 7a). Punctures are present in all areas (domestic and wild carnivores). Pits are located in the posterior part (domestic carnivores) or in all areas of the cranium (ungulates).

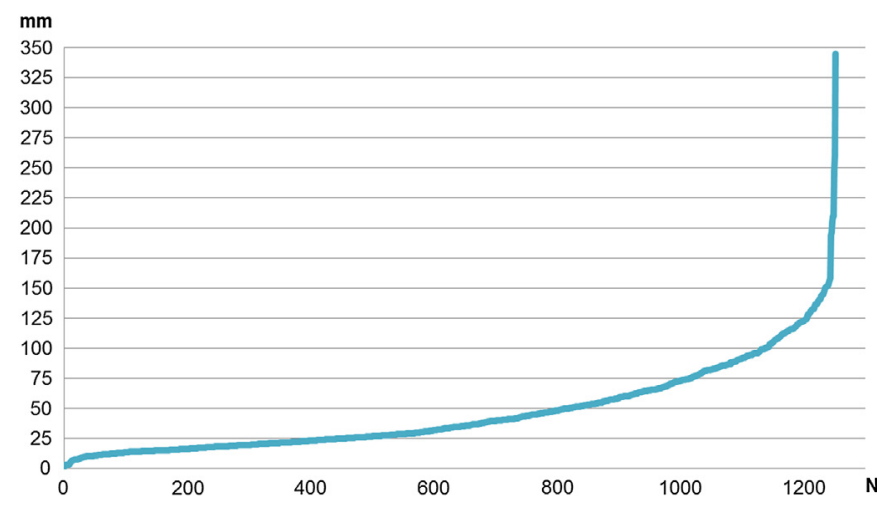

Fig. 6. Length (in $\mathrm{mm}$ ) of the remains recovered from Egyptian vulture nests (vertical axis). The horizontal axis shows the number of bones and teeth measured in the assemblage. 


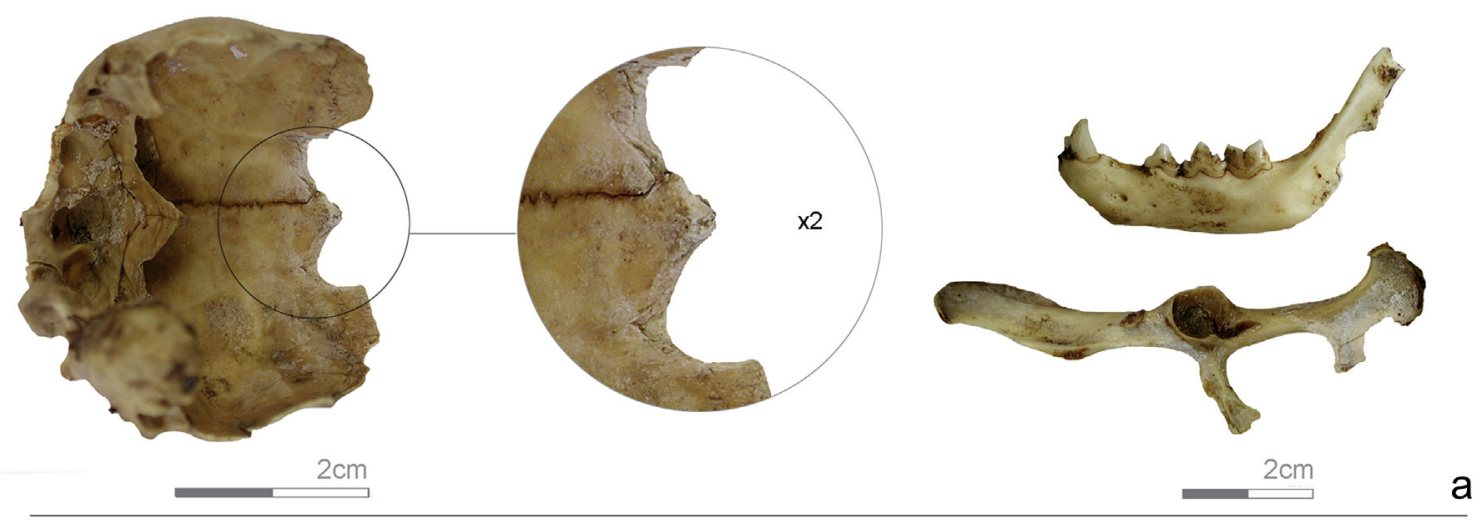

a
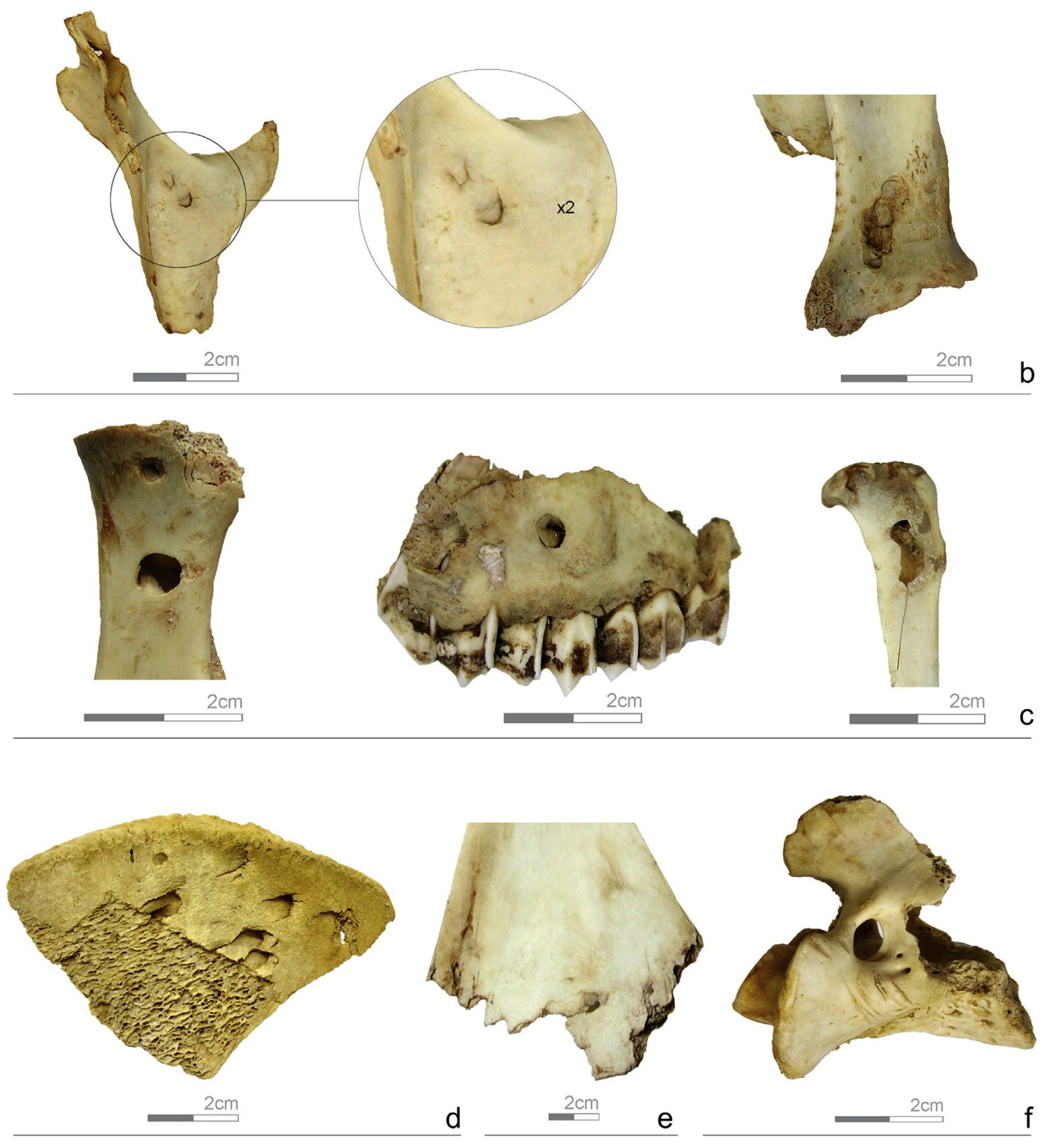

Fig. 7. Alterations by beak and/or claw impacts. a) Notches on fox skull, cat mandible and rabbit pelvis. b) Pits on chicken sternum and sheep/goat scapula. c) Punctures on sheep/ goat scapula and maxilla and leporid tibia. d) Crushing on equine pelvis. e) Crenulated edges on sheep/goat scapula. f) Anthropogenic cut marks and beak impacts (notch and pits) coexistence on sheep/goat cervical vertebra. 


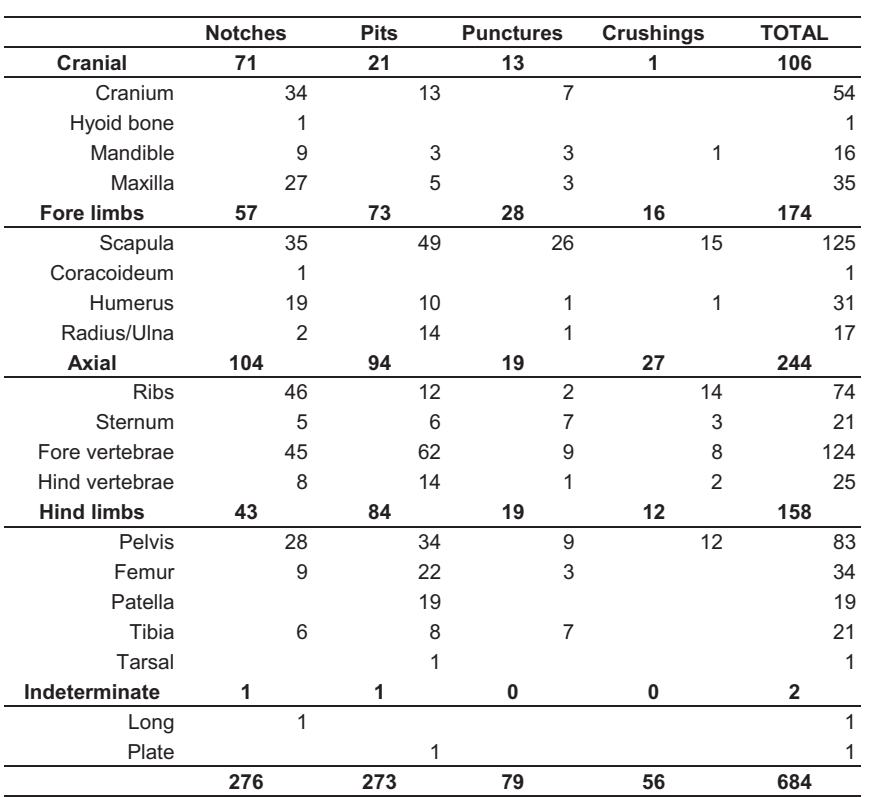

Fig. 8. Distribution of the main alterations caused by beak and/or claw impacts according to anatomical elements (NR)

- Maxilla. Punctures and notches are found in the medial part of the maxilla (ungulates and domestic carnivores) (Fig. 7c). Pits are seen in medial and posterior areas (ungulates).

- Mandible. Most notches appear in the posterior section, on the ramus (domestic carnivores and leporids). In cat mandibles, pits and punctures have been documented in addition to notches (Fig. 7a).

- Scapula. Notches are concentrated on the scapular spine and body in ungulates, and on the body in carnivores. Punctures in ungulate bones basically appear on articular areas (Fig. 7c); in domestic carnivores and leporids they are found on the body, and in wild carnivores they are found on the body and proximal section. Crushing is present on the scapular body of ungulates and domestic carnivores. Pits in the scapula appear on the neck and distal epiphysis (ungulates) (Fig. 7b); they are found on the distal section in carnivores.

- Pelvis. Notches are usually present around the ilium in the pelvis of ungulates, whereas they appear in the ischium in domestic carnivores; in leporids they are found in proximal and distal parts (ilium and ischium). In the case of ungulates, punctures are located in the ilium, although they have also been documented for other areas. Crushing is most predominant in the acetabular area and around the pelvis of ungulates (Fig. 7d) and domestic carnivores. Pits are more numerous in the acetabular area of ungulates and chickens and the ilium and acetabulum in the pelvis of cats and dogs.

- Vertebrae. Notches are chiefly located in the body and spinous process in ungulates and domestic carnivores, and in the body in leporids. Crushing has been documented on the vertebral body in ungulates and domestic carnivores. Pits in the vertebrae of ungulates are distributed over all areas (body and articular processes); in domestic carnivores they appear in the body and proximal part; in medium-sized animals they are found in the body. Notches appear in the body of the synsacrum of chickens. - Ribs. Notches, crushing, and pits are mostly documented in the body of the ribs of ungulates and medium-sized animals.

- Humerus. Notches and pits are located in the proximal epiphysis in ungulates or in this area and the diaphysis in domestic carnivores.

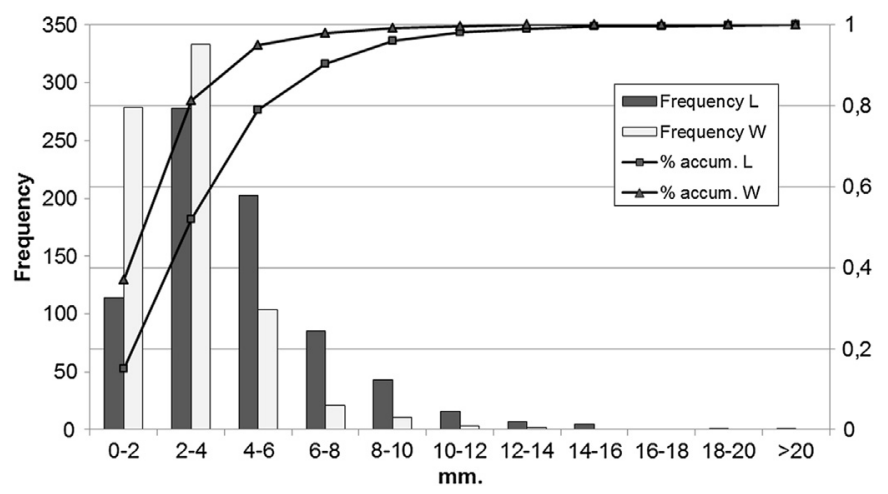

Fig. 9. Size groups (length: L and width: W) -frequencies and accumulated- of the beak and/or claw marks.

- Radius. Pits are found in the diaphysis in domestic carnivores.

- Ulna. Pits are found in the proximal epiphysis in domestic carnivores.

- Femur. Notches in the femur are located on the diaphysis and distal epiphysis in ungulates, while in leporids they are concentrated on the diaphysis. Punctures are found in the proximal articular end of the femur in chickens. There are pits in the proximal area in ungulates and chickens and in the distal area in ungulates and domestic carnivores.

- Tibia. Notches are concentrated in the proximal area of the tibia in ungulates. There are pits in the distal area of ungulate tibias and in the diaphysis in medium-sized animals. Pits are located in the proximal area of the tibiotarsi of chickens, with punctures in the distal area; notches are distributed over all areas.

- Sternum. Notches are located in the distal part of the sternum of birds and punctures are found on the body (Fig. 7b).

In addition to the characteristics and distribution of the marks, the length and width of all identified marks were also measured. If we observe the graph (Fig. 9), it can be seen that most of the measurements are under $5 \mathrm{~mm}$, with an average length of $4.5 \mathrm{~mm}$ and an average width of $2.8 \mathrm{~mm}$. Fig. 10 shows the descriptive statistics for the length and width measurements of notches, punctures and crushing.

It is possible that some terrestrial carnivores could have had access to the bones before they were collected by the Egyptian vulture. However, the lack of gnawing and low rate of scrapes, as well as the characteristics and location of the mechanical alterations that they show (notches, pits and punctures), which are largely isolated and unilateral, is not typical of the action of carnivores but of the way birds peck. We therefore associate them mainly with the Egyptian vulture's diet (e.g. Lloveras et al., 2008, 2009; Sanchis, 2012).

\subsubsection{Digested bones}

A total of 271 remains show signs of digestion (11\% of the bone sample), primarily affecting fragments (88.3\%). Most of them are

\begin{tabular}{lrrrrrr}
\hline & \multicolumn{2}{c}{ Notches } & \multicolumn{2}{c}{ Punctures } & \multicolumn{2}{c}{ Crushings } \\
\hline & \multicolumn{1}{c}{$\mathrm{L}$} & \multicolumn{1}{c}{ W } & \multicolumn{1}{c}{$\mathrm{L}$} & \multicolumn{1}{l}{ W } & \multicolumn{1}{l}{$\mathrm{L}$} & \multicolumn{1}{l}{ W } \\
\hline Mean & 5.73 & 3.04 & 4.71 & 3.55 & 5.47 & 3.85 \\
Std dev & 2.86 & 1.91 & 3.12 & 1.94 & 3.02 & 1.99 \\
Min & 0.80 & 0.50 & 1.12 & 0.95 & 1.37 & 1.00 \\
Max & 30.30 & 13.00 & 19.37 & 10.60 & 14.90 & 9.43 \\
N cases & 280 & 275 & 78 & 78 & 57 & 57 \\
\hline
\end{tabular}

Fig. 10. Descriptive statistics of the length (L) and width (W) of notches, punctures and crushings. 

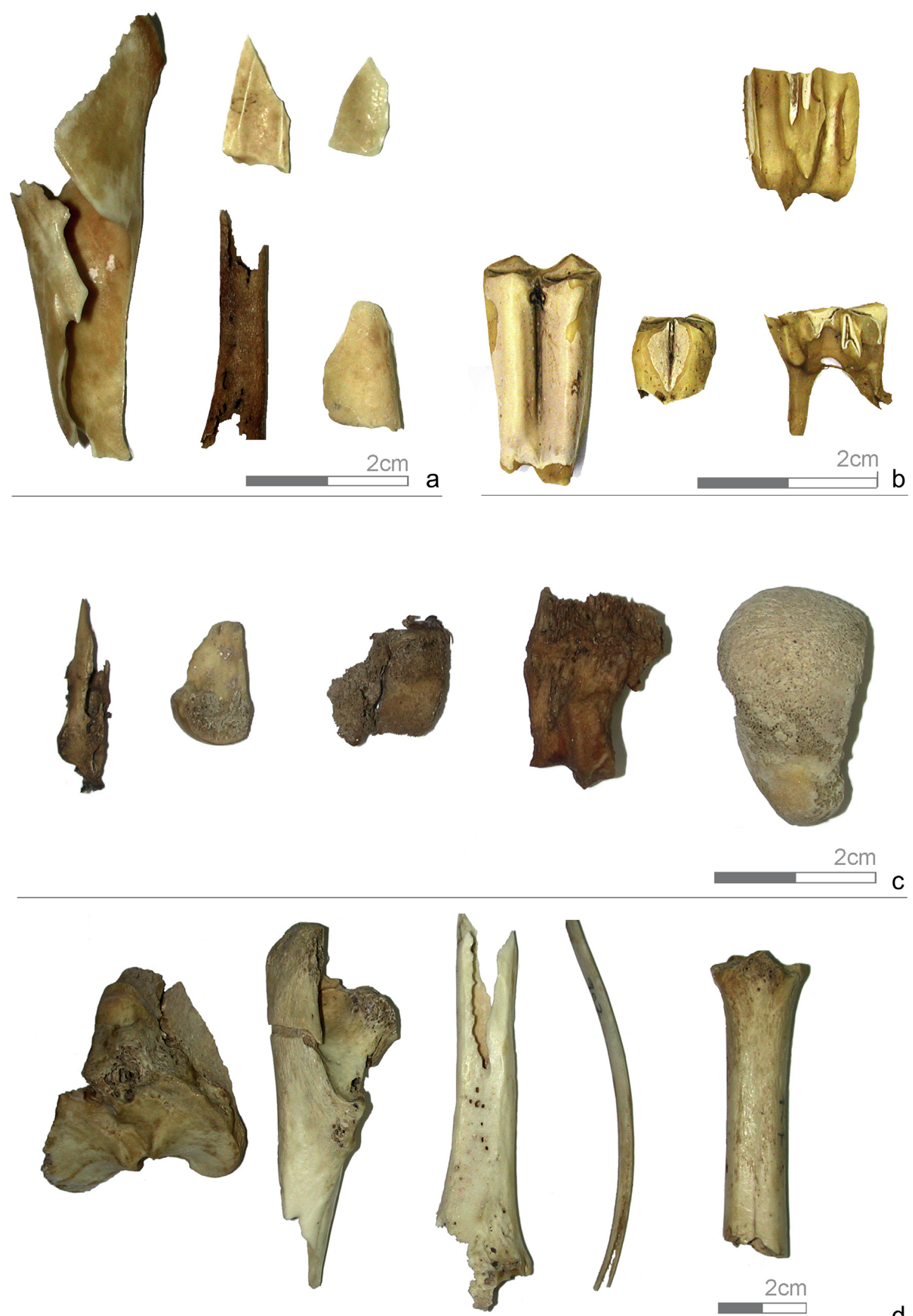

Fig. 11. Digested remains. a) Bone splinters and diaphysis fragments. b) Isolated teeth. c) Articular ends. d) Long bones and a rib. 


\begin{tabular}{|c|c|c|c|c|c|c|c|c|c|}
\hline & Total digested & Totally affecte & & Partially affected & Deformatio & & Bone loss & Polished & Porosity \\
\hline Cranial & 20 & 18 & & 2 & 7 & & 6 & 19 & 5 \\
\hline Skull & 1 & 1 & 11 & & & 4 & & 10 & 0 \\
\hline Mandible & & 8 & 6 & & 2 & 3 & & 4 & 8 \\
\hline Maxilla & & 1 & 1 & & & & & & 1 \\
\hline Fore limbs & 7 & 7 & & 0 & 5 & & 4 & 6 & 2 \\
\hline Coracoides & & 1 & 1 & & & 1 & & 1 & 1 \\
\hline Carpal-Mtc & & 1 & 1 & & & 1 & & 1 & 1 \\
\hline Scapula & & 1 & 1 & & & 1 & & & 1 \\
\hline Humerus & & 4 & 4 & & & 2 & & 2 & 3 \\
\hline Axial & 67 & 58 & & 9 & 12 & & 12 & 61 & 48 \\
\hline Ribs & 2 & 0 & 18 & & 2 & 11 & & 8 & 7 \\
\hline Sternum & & 1 & & & 1 & & & & 1 \\
\hline Cerv. Vert. & & 5 & 4 & & 1 & 1 & & 2 & 4 \\
\hline Tor. Vert. & & 1 & & & 1 & & & & 1 \\
\hline Lumb Vert & & 3 & 3 & & & & & 2 & 3 \\
\hline Sacrum & & 1 & & & 1 & & & & 1 \\
\hline Vertebrae & 3 & 6 & 33 & & 3 & & & 35 & 32 \\
\hline Hind limbs & 20 & 15 & & 5 & 4 & & 13 & 17 & 17 \\
\hline Pelvis & & 1 & 1 & & & & & & 1 \\
\hline Femur & & 5 & 1 & & 4 & 1 & & 5 & 5 \\
\hline Fibula & & 1 & 1 & & & & & & 1 \\
\hline Metatarsal & & 1 & 1 & & & & & 1 & 1 \\
\hline Metapodia & & 3 & 3 & & & 2 & & 2 & 3 \\
\hline Tibia & & 6 & 5 & & 1 & 1 & & 3 & 4 \\
\hline Tarsal & & 1 & 1 & & & & & 1 & 1 \\
\hline Tarsal-Mtt & & 2 & 2 & & & & & 1 & 2 \\
\hline Autopodium & 12 & 7 & & 5 & 2 & & 4 & 8 & 11 \\
\hline Phalanges & & 3 & 2 & & 1 & 1 & & 1 & 3 \\
\hline Phalanx 1 & & 5 & 2 & & 3 & & & 1 & 2 \\
\hline Phalanx 2 & & 4 & 3 & & 1 & 1 & & 2 & 3 \\
\hline Indet & 145 & 141 & & 4 & 58 & & 28 & 117 & 52 \\
\hline Epiphysis & $\overline{1}$ & 7 & 14 & & 3 & 4 & & 2 & 14 \\
\hline Cancellous & 3 & 2 & 31 & & 1 & 3 & & 2 & 30 \\
\hline Compact & & 1 & 1 & & & & & & 1 \\
\hline Teeth & 2 & 3 & 23 & & & 20 & & 17 & 3 \\
\hline Diaphysis & 6 & 5 & 65 & & & 28 & & 7 & 5 \\
\hline Indet. & & 3 & 3 & & & 2 & & & 3 \\
\hline Plate & & 4 & 4 & & & 1 & & & 4 \\
\hline Total & 271 & 246 & & 25 & 88 & & 67 & 228 & 135 \\
\hline
\end{tabular}

Fig. 12. Distribution of the digestive alterations according to anatomical elements (NR).

completely altered (90.7\%), with mainly polished surfaces $(84.1 \%)$ and porosities (49.8\%) in articular areas. However, bone loss (24.7\%) and structural deformations (32.5\%) were also identified. In general, the degree of digestion is strong. The most affected remains are indeterminate fragments (Figs. 11a and 12), followed by the remains of sheep, goat and small reptiles. Porosity is seen mainly in vertebrae, cancellous bones and articular bones (Figs. 11c and 12). While polish appears on shaft fragments, vertebrae and teeth, deformations and bone loss appear on teeth (Figs. 11b and 12), ribs and bone shafts (Figs. 11d and 12).

The average length of digested remains is $22.3 \mathrm{~mm}$, with a minimum of $6.5 \mathrm{~mm}$ and a maximum of $90.3 \mathrm{~mm}$. However, most of these fragments lie within the range of $10-30 \mathrm{~mm}$ (Fig. 13).

\subsection{Analysis of modern plant remains}

As regards plants accumulated by the Egyptian vultures, branches, fruits and seeds have been identified from species typical of a Mediterranean forest, the most common habitat in the vicinity of the Benaxuai caves (Fig. 14a). Other ecological environments documented in the area are a riverside habitat and crop-growing land (wines and pomegranates). The thin branches $(3-8 \mathrm{~mm}$ ) that were used to build the vultures' nests were cut between late spring and early autumn, which coincides with their nesting season, although there are too few observations to obtain conclusive data. In short, all the parameters observed suggest that Egyptian vultures accumulated twigs and other plant materials during their habitation of the cavity, which were cut expressly or collected from the ground to prepare nests. However, there are also indications that they reused wood and straw from the archaeological site located in the same cavity.

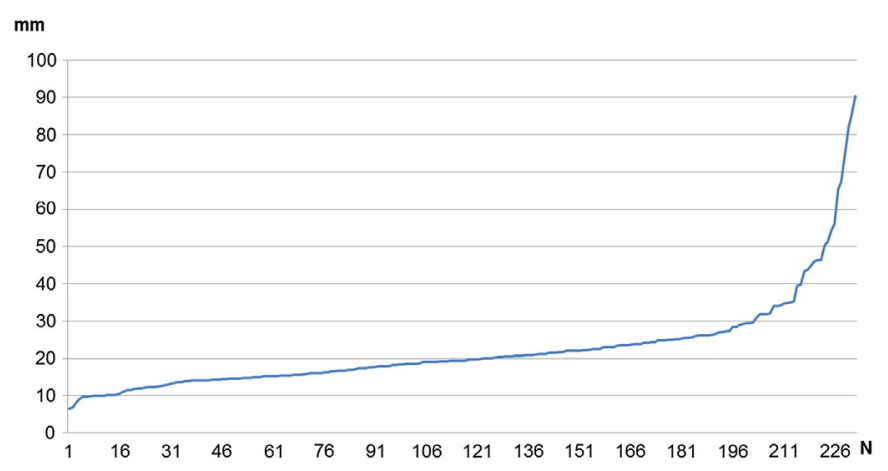

Fig. 13. Length (in $\mathrm{mm}$ ) of the digested elements recovered from Egyptian vulture nests (vertical axis). The horizontal axis shows the number of bones and teeth measured in the assemblage. 

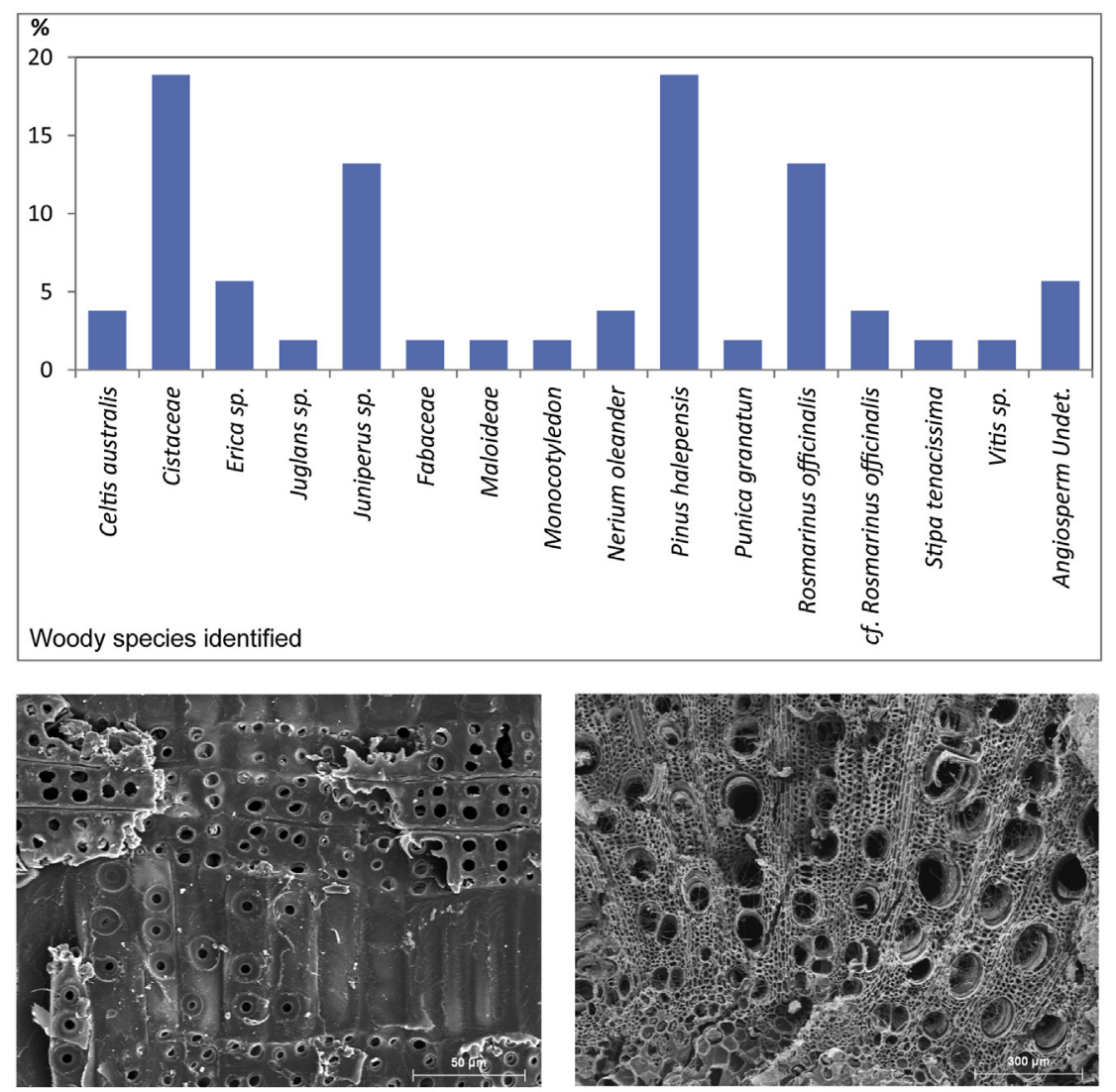

Pinus halepensis radial section

Vitis sp. cross section

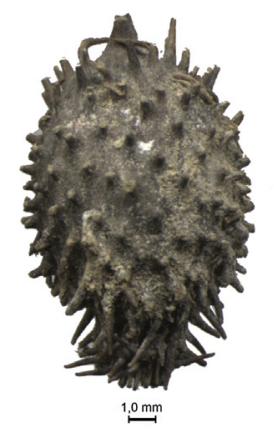

Xanthium sp. seed

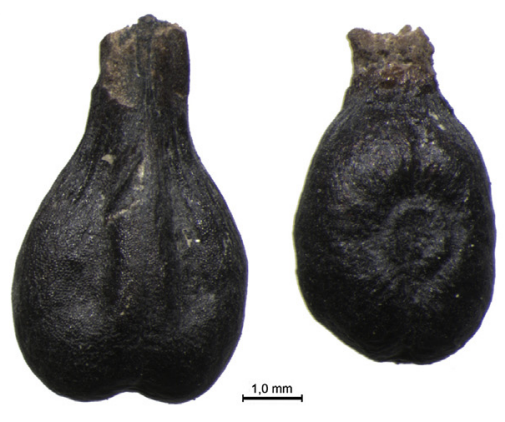

Vitis vinifera seed

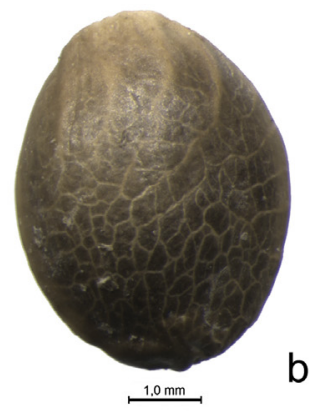

Cannabis sp. seed

Fig. 14. a) Woody species representation in C2 (\%NISP) and SEM photographs of Pinus halepensis and Vitis sp. b) Seeds identified (Xanthium sp., Vitis vinifera and Cannabis sp.).

As regards fruits and seeds (Fig. 14b), this bird seems to be opportunistically exploiting traditional local crops (Vitis vinifera, Pistacia lentiscus, Celtis australis, Punica granatum, Cucumis melo, Cucurbitacea, Phillyrea sp., Juglans regia, Prunus amygdalus, Prunus cerasus, Prunus domestica, Olea europea, Ceratonia siliqua), some of which can be consumed and digested. Another group of remains (Xanthium sp., Medicago/Melilotus and an Apiacea) is seeds whose shells or pods have pointed ends that help them stick to animals' skin or fur as a seed dispersal system. We believe that these seeds probably reached the cave either attached to the bird itself or via its prey.

\section{Discussion}

The Egyptian vulture accumulates a large amount of bone remains in its nests, which is related to its feeding habits (prey items delivered during chick-rearing). The prey spectrum indicates a great heterogeneity: it is a raptor that is opportunistic and a scavenger, focusing on small and medium-sized prey (Donázar, 1993; Margalida et al., 2012b). This suggests different places and feeding models: a) remains from human consumption (rubbish dumps), which is the basis of their diet; b) farm waste (rubbish tips); c) remains of dead animals that died accidentally or naturally as a result of collisions, disease, etc. These represent an important complement to its diet; d) in some cases, this vulture preys on animals that are easily captured or on small, young animals (Donázar, 1993). In relation to mortality profiles, domestic ungulate remains from rubbish dumps are mostly immature individuals (animals slaughtered for meat). In terms of other taxa, adults are more strongly represented.

The eminently scavenging and opportunistic feeding behavior of the Egyptian vulture and the importance of remains from human 
consumption in its diet mean that the samples show a significant bias in anatomical representation. Small carnivores, on the other hand, seem to have been transported to the nest complete. As regards leporids and birds, their size may condition the loss of some elements. In certain parts of the Iberian Peninsula medium and small species of wild animal, such as leporids, play an important part in the diet of the Egyptian vulture (Margalida et al., 2012b) and their lower representation in the samples may be due to taphonomic factors. Studying their diet by means of indirect methods, such as collecting the remains found in nests, may lead to a certain amount of bias in the skeletal profiles of the species represented (Margalida et al., 2005, 2007).

As regards conservation of the bone sample, the Egyptian vulture does not fragment many of the remains, since most of them have previously undergone a butchering process. Moreover, most of the remains of animals that died naturally or were killed accidentally remained intact. $26.7 \%$ of the set shows alterations related to the action of the beak and/or claws. Their location and morphology suggest that they were produced during the consumption of soft tissue, disarticulation processes and skull fracturing to access the brain mass. The Egyptian vulture's small size, and its beak in particular, could be the reason for the greater presence of pits than punctures in the remains found in the nests. These modifications are generally caused by beak and/or claw impacts and are concentrated in areas of lower bone density (vertebrae, ribs, scapula, pelvis, cranium). The characteristics of mechanical alterations and the low percentage of digested remains (11\%) confirm the pecking nature of this vulture. However, the ingestion of bone elements may be largely accidental, although it should also be considered that the purpose of this practice may be to obtain calcium during the nesting season, as observed in other vultures of the Iberian Peninsula (Bertran and Margalida, 1997).

The possibility of other agents having intervened before the Egyptian vultures does not seem very significant, and we believe that it does not distort the results of this study.

Some mammal excrement was found in the sample; most seem to contain only plant remains, although they are being studied. Taking into account that access to the cave by land is not viable, we believe that the remains of mammal excrement found in the cave were transported there by the Egyptian vultures. It is common for the Egyptian vulture to practise coprophagia, as feeding on excrement provides them with essential micronutrients (Negro et al., 2002). Likewise, we have found some fragments of pellets containing small bones, which we have linked to the Egyptian vulture.

As regards the plant remains found in the sample, they correspond to branches used to build the nests and seeds and fruits that occasionally served as food for these vultures.

The seasonal presence of Egyptian vultures in the area is confirmed by the presence of the ladder snake, a species that is rarely present during the months of July and August (aestivation), which means that its remains would have been added to the nest during the months of May or June (Bergier and Cheylan, 1980). This information may be complemented with the data resulting from studying the branches found in the nest. But as mentioned above, although the Egyptian vultures may have cut some branches, others could have been collected from the ground.

A comparison of these data (N. percnopterus) with those of references for the bearded vulture (Gypaetus barbatus), a bone-eating vulture, shows important differences in terms of anatomical representation and percentages of elements digested, while the taxonomic composition is quite similar in both, consisting mostly of medium-sized ungulates, although a greater diversity of species is seen in the case of the Egyptian vulture. The materials found in bearded vulture nests in Corsica (Robert and Vigne, 2002a, b) mostly consist of compact, fatty small bones (Margalida, 2008a), such as carpals, tarsals, sesamoids and phalanges, especially distal ones, with very few bone splinters, whereas the bone set from the Egyptian vulture nests contains very few of these elements but does contain more scapula and pelvis bones and cranial remains, as well as long bones. Bone splinters are also more numerous in this set. Most of the bones existing in northeastern Spain bearded vulture nests are of a high nutritional value (Margalida, 2008a, b), contrary to what is observed in Egyptian vulture nests. The bones have undergone an extremely high degree of digestive alteration in both species, but these digested bones represent different proportions of the set: more than $50 \%$ in the bearded vulture versus $11 \%$ in the Egyptian vulture. Another significant difference between these two vultures is the absence of mechanical alterations in the remains from the bearded vulture nests and ossuaries, compared with the percentage found for the Egyptian vulture (Robert and Vigne, 2002a, b; Davis et al., 2007; Marín-Arroyo et al., 2009; Marín-Arroyo and Margalida, 2012). However, certain differences can be established in comparison with other birds of prey in terms of the dimensions and frequency of the alterations caused by beak/ claw impacts. For example, in leporid bone sets recently found in eagle owl (Bubo bubo) nests (Cochard, 2004), these alterations are slightly smaller than those described for the Egyptian vulture, although never by more than 3\% (Cochard, 2004; Lloveras et al., 2009), with even lower percentages among the remains found in Spanish imperial eagle (Aquila adalberti) pellets (Lloveras et al., 2008). The dimensions of these alterations therefore seem to be related to the size of the beak/claws, whereas their frequency depends on each bird of prey's eating habits and the age and size of the prey.

The bones found in bearded vulture ossuaries, unlike those found in their nests, are mainly rejected long bones with no digested remains (Robert and Vigne, 2002a, b; Margalida, 2008a, b). The digestive processes of terrestrial carnivores also considerably affect bone remains, which are sometimes comparable to or even greater than those of birds, as is the case with wolves (e.g. Binford, 1981) or hyenas (e.g. Sutcliffe, 1970), which are usually accompanied by other evidence such as coprolites, gnawed and chewed bones, missing articular parts and the presence of complete diaphyses. Such characteristics are not seen in the Egyptian vulture sample studied here or in bearded vulture nests (Marín-Arroyo and Margalida, 2012).

\section{Conclusion}

The characteristics of the bone set studied here differ from those found in accumulations belonging to other vultures of the Iberian Peninsula, such as the bearded vulture, and in general from those of terrestrial carnivores too.

The data presented in this study confirm that the Egyptian vulture is an important taphonomic agent that is capable of accumulating and altering bone remains in its nests. The sample studied is a closed set, undisturbed by other terrestrial predators although it is possible that other predators or carrion-eating agents may have intervened previously.

According to our results, the bone sets found in Egyptian vulture nests are characterised by the fact that a heterogeneous range of prey is represented, with the predominance of two main groups; the first consists of young sheep and goats with highly fragmented remains from human waste, and the second is formed by small to medium-sized carnivores and also by mainly adult and subadult lagomorphs, both with scarcely fragmented remains. The fact that the Egyptian vulture is a carrion-eating bird and the size of its prey lead to bias in the anatomical representation of certain species. The action of the Egyptian vulture's beak and/or claws as it feeds has resulted in alterations affecting much of the sample, especially 
notches, pits and punctures that mostly appear to be isolated and unilaterally distributed. There are fewer digested bones but they have been digested to a greater degree.

The rupicolous nesting habits of the Egyptian vulture enable this raptor's intervention in archaeological sites (caves, rock shelters). These characteristics make it even more significant as a model to study archaeological bone sets.

\section{Acknowledgements}

The excavation of the Benaxuai caves has been carried out under the ordinary programme of excavations of the Servei d'Investigació Prehistòrica de la Diputació de València. This paper is part of the HAR2011-24878 project "Paleolítico medio final y Paleolítico superior inicial en la región mediterránea ibérica (Valencia y Murcia)". We are grateful to Dr. Helena Bonet and José Fornés for their support and collaboration. The authors would like to express their sincerest thanks to Dr. Ana Belén Marín-Arroyo and Dr. Marta Moreno-García for the organization of the 2nd ICAZ Taphonomy Working Group Meeting. We thank two anonymous reviewers and the editor for their helpful comments on earlier drafts of the manuscript.

\section{References}

Andrews, P., 1990. Owls, Caves and Fossils. The University of Chicago Press, Chicago. Bergier, P., Cheylan, G., 1980. Status, succès de reproduction et alimentation du vatour percnoptère Neophron percnopterus en France Mediterranéenne. Alauda 48, 75-97.

Bertran, J., Margalida, A., 1997. Griffon vultures (Gyps fulvus) ingest bones in the ossuaries of bearded vultures (Gypaetus barbatus). Journal of Raptor Research 31, 287-288.

Binford, L.R., 1981. Bones, Ancient Men and Modern Myths. Academic Press, New York.

Bochenski, Z.M., 2005. Owls, diurnal raptors and humans: signatures on avian bones. In: O'Connor, T. (Ed.), Biosphere to Lithosphere. New Studies in Vertebrate Taphonomy, 9th ICAZ Conference, Durham, 2002, pp. 31-45.

Bochenski, Z.M., Tornberg, R., 2003. Fragmentation and preservation of bird bones in uneaten food remains of the Gyrfalcon Falco rusticolus. Journal of Archaeological Science 30, 1665-1671.

Bochenski, Z.M. Tomek, T., Tornberg, R., Wertz, K., 2009. Distinguishing nonhuman predation on birds: pattern of damage done by the white-tailed eagle Haliaetus albicilla, with comments on the punctures made by the golden eagle Aquila chrysaetos. Journal of Archaeological Science 36, 122-129.

Boessneck, J., von den Driesch, A., 1980. Tierknochenfunde aus der südpanischen höhlen. In: Studien über frühe Tierknochenfunden von der Iberischen Halbinsen 7, pp. 1-83.

Bull, G., Payne, S., 1982. Tooth eruption and epiphisial fusion in pigs and wild boar In: Payne, S., Wilson, B., Grigson, C. (Eds.), Ageing and Sexing Animal Bones from Archaeological Sites, British Archaerological Reports International Series, vol. 109, pp. 55-72.

Cappers, R., Bekker, R.M., Jans, J.E.A., 2006. Digitale Zadenatlas Van Nederland. Barkhuis publishing \& Groningen University Library, Groningen.

Ceballos, O., Donázar, J.A., 1988. Selección del lugar de nidificación por el alimoche (Neophron percnopterus) en Navarra. Munibe (Ciencias Naturales) 40, 3-8.

Cochard, D., 2004. Les Léporidés dans la subsistance paléolithique du sud de la France. Thèse de 3ème cycle. Université Bordeaux I-France.

Costamagno, S., Robert, I., Laroulandie, V., Mourre, V., Thiebaut, C., 2008. Role du gypaète barbu (Gypaetus barbatus) dans la constitution de l'assemblage osseux de la grotte du Noisetier (Frechet-Aure, Hautes-Pyrennes, France). Annales de Paléontologie 94, 245-265.

Davis, S., Robert, I., Zilhão, J., 2007. Caldeirão cave (Central Portugal) - whose home? Hyaena, man, bearded vulture. Courier Forschungsinstitut Senckenberg 259, 213-226.

Dies, I., 2004. Neophron percnopterus. Banco de datos Biodiversidad. Generalitat Valenciana. http://bdb.cma.gva.es/.

Dodson, P., Wexlar, D., 1979. Taphonomic investigations of owl pellets. Paleobiology 5 (3), 275-284.

Donázar, J.A., Ceballos, O., 1988. Alimentación y tasas reproductoras del alimoche (Neophron percnopterus) en Navarra. Ardeola 35 (1), 3-14.

Donázar, J.A., 1993. In: Reyero, J.M. (Ed.), Los buitres ibéricos: biología y conservación (Madrid).

Donázar, J.A., 2004. Alimoche Neophron percnopterus. In: Madroño, A., González, C. Atienza, J.C. (Eds.), Libro rojo de las aves de España. Dirección General para la Biodiversidad-SEO/BirdLife, Madrid, pp. 166-167.

Elorza, M., 1990. Restos de aves en los yacimientos prehistóricos vascos. Estudios realizados. Munibe 42, 263-267.
Gallardo, M., Penteriani, V., 2002-2007. Alimentation: régime et comportements alimentaires. In: Synthèse bibliographique. Plan national de restauration du vautour percnoptère (Linné 1758) Neophron percnopterus percnopterus en France. Minister de l'amenagement du territoire et de l'environnement. Direction de la nature et des paysages.

Greguss, P., 1955. Identification of Living Gymnosperms on the Basis of Xylotomy Akadémiai Kiado, Budapest.

Greguss, P., 1959. Holzanatomie der Europaïschen Laubhölzer und Straücher. Akadémiai Kiado, Budapest.

Guillem, P.M., Martínez Valle, R., 1991. Estudio de la alimentación de las rapaces nocturnas aplicado a la interpretación del registro faunístico arqueológico. Saguntum PLAV 24, 23-34.

Hernández Carrasquilla, F., 1994. Addenda al catálogo provisional de yacimientos con aves del cuaternario de la Península Ibérica. Archaeofauna 3, 77-92.

Hidalgo, S., Zabala, J., Zuberogoitia, I., Azkona, A., Castillo, I., 2005. Food of the Egyptian vulture (Neophron percnopterus) in Biscay. Buteo 14, 23-29.

Hillson, S., 1986. Teeth. Cambridge Manuals in Archaeology. Cambridge University Press, Cambridge.

Horard-Herbin, M.P., 2000. Dog management and use in the late Iron Age: the evidence from gallic site of Leroux (France). In: Janet Crockford, S. (Ed.), Dogs through Time: an Archaeological Perspective. ICAZ 98, British Archaeological Research International Series 889, pp. 115-121.

König, C., 1983. Interspecific and intraspecific competition for food among old world vultures. In: Wilbur, S.R., Jackson, J.A. (Eds.), Vulture Biology and Management. Univ. of California Press, Berkeley, CA, U.S.A, pp. 153-171.

Kruuk, H., 1967. Competition for food between vultures in East Africa. Ardea 55, 171-193.

Laroulandie, V., 2005. Anthropogenic versus non-anthropogenic bird bone assemblages: new criteria for their distinction. In: O'Connor, T. (Ed.), Biosphere to Lithosphere. New Studies in Verterbrate Taphonomy, 9th ICAZ Conference. Durham, 2002, pp. 25-30.

Lauk, H.D., 1976. Tierknochenfunde aus bronzezei Hichen Siedlungen bei Monachi und Purullena (Prov. Granada). In: Studien über frühe Tierknochenfunden von der Iberischen Halbinsen, vol. 6, pp. 1-109.

Lloveras, L., Moreno-García, M., Nadal, J., 2008. Taphonomic study of leporid remains accumulated by the spanish imperial eagle (Aquila adalberti). Geobios 41 91-100.

Lloveras, L., Moreno-García, M., Nadal, J., 2009. The eagle owl (Bubo bubo) as a leporid remains accumulator: taphonomic analysis of modern rabbit remains recovered from nests of this predator. International Journal of Osteoarchaeology 19, 573-592.

López, P., García-Ripollés, C., 2007. Tamaño poblacional y parámetros reproductores del alimoche común (Neophron percnopterus) en la provincia de Castellón, Este de la península Ibérica. Dugastella 4, 49-52.

Lyman, R.L., 2008. Quantitative Paleozoology. In: Cambridge Manuals in Archaeology. Cambridge University Press, Cambridge.

Margalida, A., 2008a. Bearded vultures (Gypaetus barbatus) prefer fatty bones. Behavioral Ecology and Sociobiology 63, 187-193.

Margalida, A., 2008b. Presence of bone remains in the ossuaries of bearded vultures Gypaetus barbatus: storage or nutritive rejection? Auk 125, 560-564.

Margalida, A., Bertran, J., Boudet, J., 2005. Assessing diet of nestling Bearded vultures: a comparison between direct observation methods. Journal of Field Ornithology 76, 40-45.

Margalida, A., Mañosa, S., Bertran, J., García, D., 2007. Biases in studying the diet of the Bearded vulture. Journal of Wildlife Management 71, 621-1625.

Margalida, A., García, D., Bertran, J., 2012a. Els Voltors a Catalunya. Biologia, conservació i síntesi bibliogràfica. Editorial Grup d’Estudi i Protecció del Trencalòs.

Margalida, A., Benítez, J.R., Sánchez-Zapata, J.A., Ávila, E., Arenas, R., Donázar, J.A. 2012b. Long-term relationship between diet and breeding success in a declining population of Egyptian vulture Neophron percnopterus. Ibis 154, 184-188.

Marín-Arroyo, A.B., Fosse, P., Vigne, J.D., 2009. Probable evidences of bone accumulation by Pleistocene bearded vulture at the archaeological site of El Mirón Cave (Spain). Journal of Archaeological Science 36, 284-296.

Marín-Arroyo, A.B., Margalida, A., 2012. Distinguishing bearded vulture activities within archaeological contexts: identification guidelines. International Journal of Osteoarchaeology 22, 563-576.

Negro, J.J., Grande, J.M., Tella, J.L., Garrido, J., Hornero, D., Donázar, J.A., SánchezZapata, J.A., Benítez, J.R., Barcell, M., 2002. Coprophagy: an unusual source of essential carotenoids. Nature 416, 807-808.

Payne, S., 1982. Eruption and wear in the mandibular dentition as a guide to ageing Turkish Angora goats. In: Payne, S., Wilson, B., Grigson, C. (Eds.), Ageing and Sexing Animal Bones from Archaeological Sites, British Archaeological Research International Series 109, pp. 155-206.

Reitz, E.J., Wing, E.S., 1999. Zooarchaeology. In: Cambridge Manuals in Archaeology. Cambridge University Press, Cambridge.

Ribera, A., 2010. Las cuevas de Benaxuai. Un grupo de cuevas-ventana andalusíes en el río Chelva (Valencia). Cuadernos de Madinat al-Zahra 7, 343-367.

Ribera, A., Bolufer, J., 2008. Les covetes dels Moros. Coves-finestra de cingle al País Valencià. In: González Simancas, M. (Ed.), Les casetes dels Moros del Alto Clariano. Reedició de l’original de 1918, Col·lecció Estudis Locals, vol. 1, pp. 9 51. Bocairent.

Robert, I., Vigne, J.D., 2002a. The bearded vulture (Gypaetus barbatus) as an accumulator of archaeological bones. Late Glacial assemblages and present-day reference data in Corsica (Western Mediterranean). Journal of Archaeological Science 29, 763-777. 
Robert, I., Vigne, J.D., 2002b. Bearded vulture (Gypaetus barbatus) contributions to the constitution of two different bone assemblages: modern reference data and an archaeological example in Corsica. Acta Zoologica Cracoviensia 45 (special issue), 319-329.

Sanchis, A., 2000. Los restos de Oryctolagus cuniculus en las tafocenosis de Bubo bubo y Vulpes vulpes y su aplicación a la caracterización de registro faunístico arqueológico. Saguntum PLAV 32, 31-50.

Sanchis, A., Morales, J.V., Pérez Ripoll, M., Ribera, A., Bolufer, J., 2010. A la recerca de dades referencials per a l'estudi de restes òssies procedents d'acumulacions de rapinyaires diürnes rupícoles: primeres valoracions sobre els conjunts de Benaxuai-I (Xelva, València). Archivo de Prehistoria Levantina XXVIII, 403-410.

Sanchis, A., Morales, J.V., Pérez Ripoll, M., Ribera, A., 2011a. À la recherche d’un référentiel pour l'étude des restes de petits vertébrés provenant d'accumulations de rapaces diurnes rupicoles: les ensembles des grottes-fênetres de la rivière Tuéjar (Chelva, Valencia, Espagne). In: Laroulandie, V., Mallye, J.B., Denys, C. (Eds.), Taphonomie des Petits Vertébrés: Référentiels et transferts aux fossiles, Actes de la Table Ronde du RTP Taphonomie, Talence 20-21 Octobre 2009, pp. 57-63. British Archaeological Reports S2269.
Sanchis, A., Morales, J.V., Pérez Ripoll, M., 2011b. Creación de un referente experimental para el estudio de las alteraciones causadas por dientes humanos sobre huesos de conejo. In: Morgado, A., Baena, J., García, D. (Eds.), La investigación experimental aplicada a la arqueología, Segundo Congreso de Arqueología Experimental, Ronda (Málaga), pp. 343-349.

Sanchis, A., 2012. Los lagomorfos del Paleolítico medio en la vertiente mediterránea ibérica. Humanos y otros predadores como agentes de aporte y alteración de los restos óseos en yacimientos arqueológicos. In: Serie de Trabajos Varios del Servicio de Investigación Prehistórica, vol. 115. Valencia.

Schweingruber, F.H., 1990. Anatomie Europäischer Hölzer. Haupt, Bern und Stuttgart, p. 800.

Silver, I.A., 1969. The ageing of domestic animals. In: Brothwell, D.R., Higgs, E.S. (Eds.), Science in Archaeology. Thames and Hudson, London, pp. 283-302.

Sutcliffe, A.J., 1970. Spotted hyena: crusher, gnawer, digester and collector of bones. Nature 227, 1110-1113.

Villa, P., Mahieu, E., 1991. Breakage patterns of human long bones. Journal of Human Evolution 21, 27-48.

Zohary, D., Hopf, M., 1993. Domestication of Plants in the Old World. Clarendon Press, Oxford. 